\title{
Nietzsche's Ethics of Power and the Ideas of Right, Justice, and Dignity
}

\author{
BEATRIX HIMMELMANN
}

\begin{abstract}
In this article, I first show in which ways Nietzsche's doctrine of the will to power informs his understanding of practical ideas, such as right, justice, and dignity. Subsequently, I challenge his view by contrasting it with approaches that emphasize the significance of thinking beyond power relations. Particularly, I draw on arguments brought forward by three major figures of the philosophical tradition, namely Plato, Kant, and Schiller, all of whom Nietzsche criticizes. While they maintain the unique reality and far-reaching impact of ideas of reason that defy any given constellation of powers, Nietzsche does not accept orders independent of the fabrics of power. I discuss the implications of Nietzsche's position and finally argue, in accordance with the tradition, that there is a specifically human capacity for reflection that reaches beyond the antagonisms of power. Nonetheless, it is neither obscure nor weird nor dogmatic, but provides for a kind of orientation that is indispensable.
\end{abstract}

Keywords: will to power, antagonism, right, justice, dignity

With good reason, Nietzsche's idea of the will to power is considered the focal point of his thinking. It allows for exploring the essential features of Nietzsche's philosophical project, and for critically looking into its viability. Is Nietzsche right to claim that striving for power has to be regarded as the one and only pivotal drive that grounds human activity? Or do we have to assume counterforces, perhaps ethical counterforces in particular, that oppose or ought to oppose power and striving for power? ${ }^{1}$

Seeking an answer to this question appears to be challenging and puzzling, not least because Nietzsche's philosophy of power includes and even highlights the aspect of "plurality," a plurality of forces working against each other. Hence, it might well be that there is nothing pointing beyond individual and collective power and striving for power. If this were so, Nietzsche

JOURNAL OF NIETZSCHE STUDIES, Vol. 48, No. 2, 2017

Copyright @ 2017 The Pennsylvania State University, University Park, PA 
presumes, we would "have earned the right to clearly designate all efficacious force as: will to power" (BGE 36). ${ }^{2}$ What, pertaining to tradition, had been seen as a counterpoise to power, setting limits to its legitimacy and exercise, for instance claims of right, truth, and morality, would then have to be exposed as a specific constellation between different powers. Any contention to the effect that right, truth, and justice are grounded in orders independent of power and the fabrics of power would then have to be recognized as nothing but an ideology for the purpose of obscuring the realities.

Nietzsche is occupied with advancing a philosophical account of human existence that pays tribute to its finitude, though in terms of unreserved affirmation. ${ }^{3}$ His theory of power seems to provide precisely this kind of account, allowing for tracing back literally everything including all our so-called values to a particular relation between different powers affecting each other. There is nothing, according to Nietzsche, that "is" beyond these power relations; ideas of right, of good and evil, or of dignity that are said to transcend them have to be seen as mere "fictions [Fiktionen]" (see, e.g., $T I$ "Reason" 2). They serve as a means of eschewing the radical finitude of our existence which, as Nietzsche suggests, we should not only endure but embrace. The anti-Platonic impetus of this position is evident.

\section{Power and Productive Antagonism}

There is one feature of power that Nietzsche emphasizes from the outset: power is relational. We cannot sensibly think of any power unless we think of it in relation to another power. Nietzsche was clear about this early on, as we can see, for instance, from the opposition between the Apollonian and the Dionysian, which he explicitly introduces as "powers" $(B T$ 2, 4). The ancient Greeks happily welcomed them both: Accepting the structural conflict between these powers, they were able to develop a tragic understanding of the world that did not shy away from its lack of harmony and consistency. Apollonian lucidity, transparence, and beauty form a contrast with the Dionysian principle of dissolution and destruction, breaking up shape and individuality, and standing for opacity and enigma. What is crucial is the tension between these complementary powers. It provides for the energy needed to take a stance toward life that rises up to the challenge its ambiguity poses for any human being. Taken 
by itself and released from the connection to its counterpart, each of these powers would inevitably lead to all kinds of pernicious imbalance: the Apollonian to stagnation and to sclerotic structures, ruling out flow and change, and the Dionysian to nothing but momentum, to mere flux, dispersing difference and form.

Productive antagonism, indispensable for individual and collective enhancement, figures prominently in Nietzsche's discussions on a variety of topics. We might think of his account of the agonic fabric of Greek culture and civilization in the early piece $H C$, according to which the Greeks owe their most admirable achievements to "rivalry amongst powers [Wettspiel der Kräfte]" (KSA 1, p. 789). We might also think of the necessity to adopt historical as well as unhistorical perspectives, as only both of them, taken together, make us ready "for life and for action" (KSA 1, p. 245). Nietzsche discusses their intricate relationship in his meditation, $H L$. And we might mention the contrasting or even contradictory conceptions of the "overman" and the eternal recurrence of all things, which are put side by side in $Z$.

It is within the framework of this approach, highlighting the ambivalence of our perspectives and the need for changing our viewpoints, that Nietzsche's concept of power takes shape. With regard to an opinion, still occasionally held, that the will to power is nothing else than leaving out brute strength or even violence, it is important to reconsider: When treating power and the will to power, Nietzsche always deals with a relation between units that bear a certain strength and force including intellectual significance and value. Nietzsche conceives of power in its different physical, psychological, and intellectual facets. However, as an isolated, absolute power it can never even be thought. It is in need of an Other, in order to be power at all. It would be an empty power without something to confront, like swinging at nothingness. That is, it needs a resistance, a counterforce against which it reveals and unfolds itself as a power. So absolute power, a single power-correctly conceived - is a non-thing. Consequently, where we speak sensibly of power there is always already posited at least one further power, acting as a counterforce. Accordingly, Nietzsche writes: "The will to power can only manifest itself against resistances; it seeks for that which stands against it" (KSA 12:9[151], 424). ${ }^{4}$

All human life, split into singularities, into different centralities-life at all, indeed-Nietzsche claims, is led through power that seeks not only its own preservation, but also a perfection of what it is and shows itself as 
a power. In this sense, the will to power is creative. As mentioned, it can unfold only in conflict with another will to power. This is the reason why it wants nothing less than its antipode. In Zarathustra's speech "Of SelfOvercoming," we find an illuminating passage shedding light on this feature of the will to power and its eminent (practical) importance. This speech addresses the "wisest of men," who call will to truth what in fact is will to power. Life itself, Zarathustra lets them know, has spoken to him of the will to power and its inherent focus on self-overcoming: "That I have to be struggle and becoming and goal and conflict of goals: ah, he who divines my will surely divines, too, along what crooked paths it has to go! / Whatever I create and however much I love it-soon I have to oppose it and my love: thus will my will have it" (KSA 4, p. 148).

Nietzsche's mention of enemies, which the courageous and strong man desires-a mention that at first sight seems disconcerting-can be understood in this sense (see, e.g., GS 347). Such enemies as you may find, for instance, in contradicting opinions, opposing convictions, and different beliefs, pose a challenge to him and enable him to grow. Contrariwise, fanaticism that makes people stick to a single conviction as an unshakable certainty is actually an unmistakable sign of their weakness and insecurity. The extent of one's flexibility of thinking becomes the measure for one's ability to cope with life and, moreover, thrive. Denying life is, in Nietzsche's eyes, a mode of thinking that is unable to tolerate the fact that the meaning of things can be determined only relative to and contingent on the particular situation we face.

With all necessary determination, interpretation, and valuation we give shape to our lives, and therein lies a creative "passion" (Lust). Against the resistance of what opposes us, our convictions, interpretations, and virtues have to be developed, following Nietzsche-and they have to be overcome time and again. Only at the cost of paralysis, going hand in hand with the denial of reality, could such permanent "revaluation of values" (Umwerthung aller Werthe) be suspended.

Accordingly, there cannot be anything absolute, nothing that is unconditionally valid, no final meaning or last word, nothing to be affirmed or negated without qualification in this world and for the human being belonging to it. This is Nietzsche's conclusion and a result of his doctrine of the will to power, which can be viewed as the foundation of his philosophy, that is, his attempt at mapping out an adequate understanding of the world and of us, the human beings, as part of this world. 
It is obvious that Nietzsche's account exhibits anti-Platonic and anti-Christian traits. There is no room for something good per se, which Plato captures in terms of the Form of the Good, or for the idea of salvation, the idea that we could be redeemed from the antinomies of life and from its finitude. Nietzsche considers ideas like these detrimental to the productive play of forces that is the epitome of being alive. "Everything absolute belongs to pathology," we read in BGE 154. "Objection, infidelities, cheerful mistrust, a delight in mockery": these have to be seen, by contrast, as "symptoms of health" (BGE 154). (BU) do these considerations also pertain to our concepts of right and justice, of morality, truth, and dignity? What do we mean by saying that right and justice, moral goodness, truth and what we call human dignity have to be thought of as relational, if not necessarily relativistic? What does it mean not only to accept these standards as powers of limited significance but also to hail them as such-for the sake of life? How could we explain that we want their opposites as well, that is, wrong, injustice, moral evil, untruth, and lack of dignity-precisely because opposition to and resistance against any singular power, whatever it may be, are requirements and are to be endorsed and encouraged?

To render the basic conception of Nietzsche's philosophy sustainable, we will have to find plausible answers to these questions. Precisely by inquiring into those ideas traditionally deemed counterpoises to power, confining its legitimacy and exercise, the validity of Nietzsche's philosophy of power has to be explored. Right and justice count among the most important of these ideas. For that reason we will turn to them first.

\section{Are There Limits to Power? Nietzsche's Concepts of Right and Justice}

As early as in his second Untimely Meditation, Nietzsche argues that injustice belongs to human life substantially. All our doings, he declares, are full of "blindness" and "one-sidedness" (KSA 1, pp. 253-54). With every action we do commit ourselves to only one of the available options, excluding all the other possibilities in spite of the authority and the right that seem to be with them. In this respect any agent is always "without conscience [gewissenlos]," Nietzsche remarks, referring to Goethe (KSA 1, p. 254). ${ }^{5}$ Justice, he concludes, is an "impossible virtue [eine unmögliche Tugend]" (HL; KSA 1, p. 286). 
Nonetheless, we need concepts of justice and we develop them, Nietzsche reckons, in accordance with those power structures that underlie all conduct of human life. He conceives of justice as a balance, a settlement concerning the claims powers have on each other. For Nietzsche, the origin of justice rests on the prerequisite of approximately equal strength that the powers possess $(\mathrm{HH}$ 92, 93). Such strength is to be measured according to the particular "power position [Machtstellung]" someone holds, that is the value or worth his power has for others. ${ }^{6}$ Nietzsche thinks that the "equilibrium of powers" is the basis of justice. ${ }^{7}$ It provides the precondition for arrangements and for the exchange of goods and services that is of advantage to the parties involved, whereas an attitude of confrontation and the possibility of mutual impairment would be thoroughly disadvantageous to them all. The prospects of weakening the other would not outweigh the probability of being harmed oneself. Hence, prudent striving for self-preservation, which all powers will pursue if only they are open to good judgment, appears to be the source of any idea of justice. Nietzsche finds his theory endorsed by "the horrifying conversation between the Athenian and Melian envoys," which Thucydides famously recounts ( $\mathrm{HH}$ 92).

A feature of all power relations that is crucial to Nietzsche, and this should not come as a surprise, is the instability or, to put it in positive terms, the dynamics inherent to them. There is a continuous shift of the formation of powers affecting one another. Even each and every human being by himself is to be seen as a "plurality of "wills to power," the interplay of which selforganizes again and again (KSA 12:1[58], p. 25). At all times, there are merely "momentary power fixations [augenblickliche Macht-Feststellungen]" indicating the particular "power status [Macht-Lage]" of a given unit (KSA 12:1[61], 26). All living things are constantly in a state of flux.

Against this background, the significance of a (reverse) will to fasten, fix, and secure things, "Fest-" and "Dauerhaft-Machen," as Nietzsche writes (KSA 12:9[91], 384), comes into view. This will manifests itself, for instance, in every contract. By contract, different parties commit themselves to acknowledging and maintaining certain firm rules of dealing with each other, regardless of any change they themselves might undergo or their environment might be subjected to in the time to come.

A contract is a promise endorsed by additional securities, and Nietzsche thinks it is an amazing achievement of mankind to be able to promise altogether. Whoever promises has to bind his or her will into an open future. By giving somebody his or her word, as we say, he or she who are unique 
individuals respectively, nonetheless, make themselves "to a certain degree necessary, uniform, a peer among peers [gleich unter Gleichen]" (GM II:2; KSA 5, p. 293). They do this, aware of their sovereignty and their strength and taking pride in their self-mastery, all of which ground the ability to assume responsibility.

Justice understood along these lines is tantamount to establishing predictability (Berechenbarkeit) in dealing with one another. In a remarkable late posthumous fragment on justice, which is perceived as the fundament of right as it is set down in contracts between parties, Nietzsche writes:

The representation of Justice with a pair of scales in her hand cannot be accepted, for it is misleading: the correct allegory would be to make Justice stand at the center of a pair of scales in such a way that she kept the two pans balanced (daß sie die beiden Schalen im Gleichgewicht hält). But Justice is wrongly represented for the most part-and the wrong words are put into her mouth as well. Justice doesn't say: "Give everyone his due," but always only: "Tit for tat." That two powers in a relation to each other rein in the reckless will to power, and not only leave each other be as equal but even want each other to be equal, is the beginning of all "good will" upon earth. For a contract contains not just a mere affirmation with respect to an existing quantum of power, but also the will to affirm this quantum on both sides as something lasting and thus, to a certain extent, themselves to maintain it. In this, as I say, is to be found a germ of all "good will." (KSA 12:5[82], p. 221 $)^{8}$

On Nietzsche's view, justice does not mean acknowledging rights that individuals as such possess-because, for example, they have to be respected as persons endowed with freedom and a will of their own. Nietzsche's mention of a "good will," referring to Kant, must not be understood in a way suggesting that he adopts Kant's idea of something good "without limitation," a qualification that, according to Kant, applies to the "good will" and to the "good will" only. " On the contrary, Nietzsche considers the fact that two powers "want each other to be equal" an "honor [Ehrung]" and an affirmation one power grants another one without the two of them owing any esteem to each other. The source of this behavior lies in "egoism," which is a mark of the "noble soul" in particular, as Nietzsche expounds in a series of aphorisms beginning from $B G E 265.10$ "noble soul's" egoism 
is accompanied by the "firm belief that other beings will, by nature, have to be subordinate to a being 'like us' and will have to sacrifice themselves." Nietzsche does not perceive this egoism as an issue of moral concern but as a plain "fact," which the noble soul accepts "without any question-mark," seeing it as "justice itself." Similarly, the "noble soul" acknowledges, selectively, "others with rights equal to its own [mit ihr Gleichberechtigte]." Nietzsche regards "this finesse and self-limitation in dealing with equals," which the noble soul imposes upon itself, as "just another piece of its egoism": for it "honors itself in them and in the rights that it gives to them." The noble soul gives and receives, Nietzsche explains in accordance with the argument spelled out in the fragment on the representation of justice quoted above, "out of the passionate and sensitive instinct of retribution that is so fundamental to it." Always only "tit for tat" justice says, as we heard before.

Thus justice is, on Nietzsche's view, a concept that is contingent on power structures and orders of rank according to which it has to be spelled out over and over again depending on the circumstances. Consequently, Nietzsche rejects (in $B G E 259$ ) a principle that would generally oblige human beings to "refrain from injuring, abusing, or exploiting one another; to equate another person's will with one's own [seinen Willen dem des Andern gleh setzen]." If this principle were taken to hold universally and wholesale, Nietzsche argues, it would immediately be revealed for what it is: "the will to negate life, the principle of disintegration and decay." Hence "states of legality," as he explains in a well-known chapter of GM (GM II:11), "can never be anything but exceptional states," "partial restrictions of the true will to life, which seeks power." Legal systems (Rechtsordnungen), Nietzsche alleges, have to be conceived of as "a means for use in the fight between units of power," a fight that he thinks is driven by two guiding forces working in opposite directions: self-preservation and self-overcoming. "Human rights [Menschenrechte]" independent of the dynamics inherent to these fights, transcending or underlying them, "do not exist [giebt es nicht]" reads a laconic résumé to be found in Nietzsche’s notebooks (KSA 8:25[1], p. 482).

\section{Looking Beyond the Forces of Finitude}

Should we agree with Nietzsche on this understanding according to which the measures of what is right and just are to be derived from the power relations in place in the given situation? We should be cautious. Even though it 
may be the case, as a matter of fact and genealogy, that might makes right, it does not follow that this ought to be so. A dimension of orientation discredited by Nietzsche, which exceeds factual power balances, could prove productive or even indispensable. Those ideas or standards against which Nietzsche inveighed could turn out to be essential at least to human life.

Whatever their foundation and justification might look like, their function would be to guide our practices in a way that goes beyond the (theoretical) assessment and (practical) response to a specific situation defined by the power balances actually in effect. Ideas understood as notions of reason providing for firm standards seem to open up a perspective that allows for a viewpoint transcending these specific situations and the constellations of power constitutive of them. It is clear that ideas like these stand in stark contrast to all the presuppositions underlying Nietzsche's concepts of right and justice. "Justice itself," we have heard, is to be found in the egoism of the strong and noble powers who affirm themselves in their striving for growth and enhancement, and they are entitled to this presumption (BGE 265).

This conception of justice, suggesting that justice shows itself in its palpable reality and palpable effects, fits in with Nietzsche's decisively antiPlatonic and anti-idealistic approach. It is linked to the attitude of the "pathos of distance," ${ }^{11}$ Nietzsche's formula for being aware and appreciative of rank differences. It stands for the right and the might from which the noble, the high-ranked and high-minded infer the license to "[see] and judg[e] themselves and their actions as good, that is first-rate," in contrast to "everything lowly, low-minded, common and plebeian" (GM I:2). Feeling and bearing themselves like this, Nietzsche insinuates, enables them to "create values" in a non-reactive and sound way. He expounds these themes, as is well known, in the first essay of GM in particular. ${ }^{12}$ They also loom large in part 9, headlined "What is noble?," of $B G E$.

The tradition, to which Nietzsche alludes when he refers not only to Kant's concept of a "good will" but also to Plato's notion of justice, had refrained from accommodating the understanding of this virtue toward the realities of power relations. In contrast to thinking that is confined to coping with and orienting itself in the finite circumstances of power relations, the tradition had argued for the indispensability of yet another dimension of thinking. This type of thinking, too, is relational thinking. But it engages the individual in a very different way and beyond responding to actual power structures, which call for this or that stance. For instance, it might be right to emphasize the Dionysian element over the Apollonian on 
one occasion because a sclerotic situation has to be resolved, but it might be adequate on another occasion to endure and accept things as they are, abiding by amor fati, because revolt and change would be inappropriate at that very moment. In situation could require us to adopt a strongly unhistorical perspective over the historicalone because it encourages decisive action immediately - and so forth. The dimension of thinking to be distinguished from such power of judgment rises above the antagonisms constitutive of our world, ${ }^{13}$ with which we have to cope, by way of confronting us, the finite human beings, with ourselves. What is at stake is definitely not any kind of disregard for this finitude or the power of judgment necessary for finding our way around under these conditions. What is at stake is the question of how to relate to this unique situation of human finitude, of which we are or, at least, can be aware. Thus it is our self-relation that comes into view now.

Just by addressing his or her finitude, however, the human being is always already involved in this kind of relation. We find it articulated in Nietzsche's writings as well, particularly when he discusses the "death of God." But he seems eager to overcome and supersede self-examination along these lines altogether since he thinks it can be revealed to originate in the idea of a "true world," which is opaque and unintelligible. ${ }^{14}$ Nietzsche recommends that we bid farewell to this sort of pernicious metaphysics. He considers it pernicious because he believes it undermines and devalues the human faculties of cognition, of perception, of moral understanding and conduct, and-last but not least-of feeling at home in the world into which human beings have been placed. According to Nietzsche, metaphysics does this work of devaluation by presenting misguided counterimages of all important human endowments, augmenting them with grades of excellence and perfection that are plainly unattainable for human beings, thus diminishing their achievements and discouraging their ambitions.

Whether or not the specter of metaphysics is rightly invoked at this point, what in fact is it that is to be said against asking, together with Plato, what we mean when we speak of justice or inquiring, together with Kant, into the idea of a good will-independently of the actual conflicts that have to be resolved? Engaging in this kind of questioning, we start to work on ourselves and our beliefs instead of merely coping with the demands of the realities in more or less complacent ways, even though involved in struggles for power with other parties proceeding as complacently as we do. Considering the "noble soul" once again, which conceives of its egoism 
as "justice itself" and is indeed willing to acknowledge "others with rights equal to its own" if and when it deems them peers, and bearing in mind Nietzsche's description according to which the "noble soul" "does not generally like looking 'upwards,--but rather ahead, horizontally and slowly, or downwards:-it knows that it is high up" (BGE 265), don't we have to say that this account gives a quite inappropriate picture of the human condition? Even though the unimpaired self-certitude evident in the passages quoted might pertain only to the so-called "higher type of '”, does it really speak in his favor ${ }^{15}$ Why do people take up the burden of reflecting on questions concerning justice, the good will, or human dignity-albeit the answers given remain contested? Obviously, they do so because they see the requirement of arguing about some of the foundations of life and its conduct in ways other than by settling contingent controversies according to the balance of powers.

Asking, for instance, whether there is a concept of justice that is binding regardless of specific power structures need not be considered senseless from the start. Pointedly, Plato's Politeia deals with this question. Given that there is a good (agathon) that we call justice and love for its own sake, and not only because it proves advantageous and useful in our exchanges with others, we would have to show that the life of the most just person, even though he is deemed the most unjust person and treated accordingly, is, nonetheless, to be preferred to the life of the most unjust person, although he appears to be the most just person and receives praise accordingly. This thought experiment is advanced by reference to the legend of Gyges and his ring. The ring provides Gyges with the opportunity of becoming invisible and, thus, allows him to do as he pleases and "conduct himself among mankind as the equal of a god" (36o c). Wouldn't Gyges as well as anyone else exploit this situation in order to satisfy all his wishes to his heart's content, which-otherwise-would be held in check by the force of law? In addition, wouldn't he be prone to giving the impression of a just man, enjoying all the honors and reputation the world has to offer? When human beings as we know them develop and implement the idea of justice after all, they do so only because they do not possess the magic spell of Gyges's ring conferring omnipotence to its bearer. Lacking in this quality, they need to anticipate relations of powers and counterpowers and make calculations accordingly. The roots of justice seem to lie in this fact, entailing the institution of laws and contracts.

This is the Sophist's argument, and we see how close Nietzsche's position comes to the Sophist's approach. Justice is of service to power, according to 
this argument, by supplementing power with prudence. So isn't Nietzsche right to claim that power always has the final say because there isn't anything else than powers and counterpowers-a fact philosophy should acknowledge?

Plato's Socrates accepts the challenge. It turns out that he can explicate a concept of justice that is intrinsically good and binding as such. Investigating, on the large scale, the constitution of the city and, on the small scale, the constitution of the individual human being, Socrates thinks he can show that they may be called just if all the forces in effect are ordered such that each of them does what it is due to do. This order is supposed to establish harmony (xymphonia) and friendship (philia) among the forces in place. What reflection judges reasonable and sound for the whole ought to rule, and all vital forces ought to comply. According to Plato, this outlook is liberating, taking us beyond the finite albeit endless cycle of maintaining, securing, and increasing power. Harmony and modesty, ever growing with insight, appear to be the basis of a just-and happy-life.

Whether we approve or disapprove of this solution, searching for what is just and unjust regardless of the balance or powers is of worth. It helps us shape our lives according to our own ideas of how they should look like. Renouncing this aspiration from the outset would diminish the horizons of thought, reduce the scale of self-understanding, and, finally, suggest that thinking amounts to no more than business sense. We need ideas to "set a direction into which we can strive," as Nicholas Rescher puts it. ${ }^{16}$ Neither fanaticism nor dogmatism need be associated with this endeavor, even though Nietzsche tends to identify it with a desire for the "true world." It seems, however, that the capacity and need for orientation that surpasses the scope of any living environment in the "real world" is given with human existence, as can be demonstrated by considering its literal meaning, that is, orientation in space. Never have human beings been content with just finding their way through their nearby environment, taking pains, for instance, to go about their business in the best possible fashion. They have always also reached out toward a totality, expanding their range of vision and thought from the whole of the earth and its inhabitants to the universe in order to position themselves in a more general way and independently of their concern for their everyday life. It is obvious that this additional perspective allows for a new and different view on their existence that does not leave it unaffected. 
Analogous to orientation in space, we can conceive of orientation through thinking. In this sphere, too, human beings do not confine themselves to what is nearby, the situation and the conflicts that have to be dealt with here and now. In thinking, too, we presume to envisage the whole, by asking questions concerning justice and injustice, guilt and responsibility, forgiveness and punishment in principle. We even seek to understand ourselves in relation and in contrast to the idea of divinity. For this sphere, too, it is true that it opens up horizons of seeing ourselves that reach beyond assessing and dealing with things in accordance with the standards derived from the actual balance of power. It is evident that this additional perspective allows for a new and different view on human existence and its stance that is not without consequences for the way we conceive of ourselves. Hence, it is not just by chance that Plato speaks of periagoge $\bar{e}$, revolution, in this regard. ${ }^{17}$

Should we rid ourselves of this dimension of reflection, which looks strange compared to the kind of thought involved when we are directly and immediately concentrated on managing things along the lines of the finite constellations of our lives? Nothing less, it seems, Nietzsche advises us to do. While metaphysics began with Plato's idea of a "true world," "attainable for the sage, the pious, the virtuous man,"18 we ought to bid farewell to it now: "The 'true' world-an idea which is no longer good for anything, not even obligating - an idea which has become useless and superfluousconsequently, a refuted idea: let us abolish it!” (TI “'True World”').

I hope it has become clear that we are going to lose a lot if we agree to confine the horizons of thinking to what is finite and provisional, emerges from and is bound to the relations among powers and counterpowers, and is of worth only contingent on the particular situation. Yet all this makes up the world of our experience-and the only world that should concern us according to Nietzsche. If we subscribe to this picture, however, we are also going to lose any substantial idea of human dignity - and this is the last point I am going to make in this article.

\section{Remarks on Human Dignity}

On the one hand, Nietzsche seems to dismiss the idea of dignity altogether. He argues that it is an empty concept, a concept insinuating meaning and worth where there actually is no meaning and worth. He claims that it 
is an invention modern slave mentality has produced. It is of service to them whose lives have been reduced to the struggle to just preserve a miserable existence. To hide this emptiness, they resort to a code suggesting the exact opposite of emptiness, trying to bestow meaning and value on their worthless ado by attributing "dignity" to it. When reflecting on their existence and their struggle, they proudly speak of the "dignity of man [Würde des Menschen]" and the "dignity of work [Würde der Arbeit]" (GSt; KSA 1, pp. 764-65). The Greeks, Nietzsche points out, did not require these ideas. They did not even have a concept of dignity. They had no need for it. According to Nietzsche, they were able to look at "the human entity [Menschending]" with "startling frankness [mit erschreckender Offenheit]," admitting that it does not matter significantly or, at least, not in ways involving the acknowledgment of a specific value called "dignity" it allegedly carries within itself (GSt; KSA 1, p. 765).

On the other hand, Nietzsche also develops a positive conception of dignity. According to this account, dignity is contingent upon rank and status, thus fitting in with Nietzsche's belief in the "pathos of distance" and with his overall philosophy of power and finitude. The slaves as portrayed above have to hide this truth from themselves, which is, however, "recognizable to every one of deeper insight [für jeden tiefer Blickenden erkennbar]"; as a result, the slaves cannot understand "what stage and level must be attained before 'dignity' can even be mentioned, which is actually the point where the individual completely transcends himself and no longer has to procreate and work in the service of the continuation of his individual life" (GSt; $K S A$ 1, p. 766). On Nietzsche's view, dignity indicates, if anything, difference and differentiation in status and significance. Dignity is ascribed to those who stand out. The people of ancient Greece, for instance, can lay claim to "the dignity and special position amongst peoples [die Würde und Sonderstellung unter den Völkern]" that are owed to "the genius amongst the mass," and the "dignity of this kind of leading position [die Würde einer solchen Führerstellung]" can also be assigned to Socrates, "the archetype of a form of existence unknown before him, the archetype of theoretical man," as Nietzsche argues in $B T$ (BT 15; KSA 1, pp. 97-98).

It seems that Nietzsche brings back into use the original meaning of the term dignitas, signifying high rank and reputation in society, which was prevalent in ancient Rome and extended, modified but structurally analogous, well into the period of Christian philosophy and thought. ${ }^{19}$ Nietzsche clearly rejects the classical notion of dignity beginning with 
Cicero's argument in De officiis, which highlights the distinction and dignity inherent to the nature of human beings as such: "excellentia et dignitas quae sit in natura nostra." 20 Our nature, however, Cicero argues along with other Stoic thinkers, is set apart by reason. Living according to nature (convenienter naturae vivere), then, is tantamount to living according to reason as soon as human beings are concerned; and reason, here, obviously carries normative implications.

In Kant's and Schiller's classical accounts, the notion of dignity is closely connected to the human capacity for reflective and practical reason, revealing human freedom because of its normative import. Nietzsche drops this idea of reason. Following Nietzsche, there are no a priori principles or ideas of reason that could orient human thinking or guide human conduct. In his understanding, reason is a force belonging to and operating in the sphere of conflict and antagonism, outside the framework of which it would lose its productivity, whereas reason may reach beyond this sphere according to Kant and Schiller. Only in virtue of this quality it vouches for the "dignity of mankind [Würde der Menschheit]," emphasize. The unique reality of "the legislation of reason from principles [Gesetzgebung der Vernunft aus Prinzipien],"22 as Schiller puts it, providing for standards of orientation that transcend any given power constellation, constitutes "the kingdom of complete freedom [das Reich vollkommener Freiheit],"23 for human beings. Whoever renounces this reality, unthoughtful or highly reflective, drags, on Schiller's view, "an enslaved soul [eine Sklavenseele]"24 around with her, confining herself to coping with life along the lines of the games of power. Does this plea for a metaphysical outlook make sense, as Kant, Schiller, and others would claim, or can it be proven a misleading presumption, as Nietzsche might insist?

At least we can say that we need not join in a lament brought forward in the third essay of GM. With an eye to the self-understanding of modern man who cannot reconcile his ambitions with the results of science, Nietzsche writes: "Gone, alas, is his faith in his dignity, uniqueness, irreplaceableness in the rank-ordering of beings, - - he has become animal, literally, unqualifiedly and unreservedly an animal, man who in his earlier faiths was almost God ('child of God', 'man of God') . . .' (GM III:25). ${ }^{25}$ We can maintain, though, that we are not at all left with only one option of inferring and justifying the concept of human dignity, namely from the idea of man being created in the image of God, an idea to which Nietzsche undoubtedly alludes in this passage. It is feasible as well as sufficient to ground human 
dignity in the human capacity for thinking beyond the forces of finitude, engaging in what Nicolai Hartmann called intentio obliqua in contrast to intentio recta. ${ }^{26}$ It is this kind of self-reflection on which human culture rests, and "culture," as Nietzsche suggests at one point, might be "nothing but a tiny piece of apple skin on top of a blazing chaos [nur ein dünnes Apfelhäutchen über einem glühenden Chaos]" (KSA 10:9[48], p. 362, my translation). It should be cherished all the more.

UiT-The Arctic University of Norway, Tromsø beatrix.himmelmann@uit.no

\section{NOTES}

I am grateful to Matthew Meyer for carefully reading my article and providing helpful feedback on a couple of language issues.

1. In what follows I am presenting a more robust reading of Nietzsche's doctrine of the will to power than is found in interpretations prevalent in today's Anglophone Nietzsche studies. Brian Leiter colorfully describes the doctrine as Nietzsche's "crackpot metaphysics" ("Nietzsche's Naturalism Reconsidered," in The Oxford Handbook of Nietzsche, ed. Ken Gemes and John Richardson [Oxford: Oxford University Press, 2013], 594). Maudemarie Clark and David Dudrick, in The Soul of Nietzsche's Beyond Good and Evil (Cambridge: Cambridge University Press, 2012, 5), say that Nietzsche's conception of the will to power, broadly construed, has to be considered "notorious." They add the remark that "Nietzsche's reputation continues to grow among serious philosophers, but always in spite of the doctrine of the will to power, never because of it." They themselves claim that the will to power is to be understood exclusively in terms of a power psychology; it has no role to play outside philosophical psychology. Arguing that $B G E$ can be read either exoterically or esoterically, either providing an account of what the "will to truth" aims at, scientific knowledge and explanation, or the "will to value" deals with, our normative commitments and their justification, they hold that the will to power solely concerns the latter project. The will to power underlies the process of organizing the different drives constituting the human soul into a "political order" as contrasted with a merely causal order (p. 175). I will not be able to discuss Clark and Dudrick's well-elaborated approach in due detail here (for a critical discussion, see Mattia Riccardi's review of their book in Notre Dame Philosophical Reviews, November 16, 2012). My own reading focuses on the relational quality pertaining to any power and the challenge Nietzsche's stance poses for any of our normative commitments. 
2. I have consulted the following translations and editions of Nietzsche's work, and where translations are my own, I provide the KSA reference: The Birth of Tragedy and Other Writings, ed. Raymond Geuss and Ronald Speirs, trans. Ronald Speirs (Cambridge: Cambridge University Press, 1999); On the Advantage and Disadvantage of History for Life, trans. Peter Preuss (Indianapolis: Hackett, 1980); Human, All Too Human, trans. R. J. Hollingdale (Cambridge: Cambridge University Press, 1996); Thus Spoke Zarathustra, ed. Adrian Del Caro and Robert B. Pippin, trans. Adrian Del Caro (Cambridge: Cambridge University Press, 2006); Beyond Good and Evil, ed. Rolf-Peter Horstmann and Judith Norman, trans. Judith Norman (Cambridge: Cambridge University Press, 2002); On the Genealogy of Morals, ed. Keith-Ansell-Pearson, trans. Carol Diethe (Cambridge: Cambridge University Press, 2007), including The Greek State (164-73) and Homer's Contest (174-81); Twilight of the Idols, in The Anti-Christ, Ecce Homo, Twilight of the Idols, and Other Writings, ed. Aaron Ridley and Judith Norman, trans. Judith Norman (Cambridge: Cambridge University Press, 2005), 153-229; Writings from the Late Notebooks, ed. Rüdiger Bittner, trans. Kate Sturge (Cambridge: Cambridge University Press, 2003).

3. For an illuminating discussion of Nietzsche's concern with human finitude and the resources the doctrine of the will to power provides in that respect, see Pavel Kouba, Die Welt nach Nietzsche. Eine philosophische Interpretation (Munich: Wilhelm Fink, 2001); for an in-depth analysis of Nietzsche's emphasis on the affirmation of life, see Bernard Reginster, The Affirmation of Life: Nietzsche on Overcoming Nihilism (Cambridge, MA: Harvard University Press, 2008).

4. "Der Wille zur Macht kann sich nur an Widerständen äußern; er sucht nach dem, was ihm widersteht." Bernard Reginster also emphasizes this specific feature of the will to power (Affirmation of Life, 103-47).

5. "Der Handelnde ist immer gewissenlos; es hat niemand Gewissen als der Betrachtende" (Maximen und Reflexionen, 241); cf. Johann Wolfgang Goethe, "Maximen und Reflexionen," in Artemis-Gedenkausgabe der Werke Goethes, vol. 9 (Munich: Deutscher Taschenbuch Verlag, 1977), 522.

6. Obviously, Nietzsche follows Thomas Hobbes, Leviathan, ed. R. Tuck (Cambridge: Cambridge University Press, 1991), chap. 10, 63, on this point.

7. See, e.g., WS 22. Seminal interpretations illuminating Nietzsche's thoughts on right and legality have been advanced by Volker Gerhardt, for instance, in Vom Willen zur Macht: Anthropologie und Metaphysik der Macht am exemplarischen Fall Friedrich Nietzsches (Berlin: de Gruyter, 1996).

8. See also the revised text of the fragment in $K G W \mathrm{IX} / 3$, pp. 67-68.

9. See Immanuel Kant, Groundwork of the Metaphysics of Morals (GermanEnglish Edition), ed. and trans. Mary Gregor and Jens Timmermann (Cambridge: Cambridge University Press, 2014), IV 393 (= AK 4:393).

10. See also $B G E 259$.

11. BGE 257; GM I:2; GM III:14.

12. All the quotes given in this paragraph are to be found in GM I:2. See also $B G E 260$. 
13. Nietzsche himself, however, would claim that there is no such dimension of thinking. For him, all thinking is just another instance of the antagonism of drives; see $G S 333$.

14. See TI “"True World”; KSA 6, pp. 80-81.

15. The concept of the "noble soul" could be spelled out in more interesting ways than the account Nietzsche gives in book 9 of $B G E$ suggests. Nietzsche could, instead, draw on the idea of a soul that takes as much as possible "on [itself], to [itself], in [itself]," aiming at totality, disciplining itself to wholeness (cf. TI "Skirmishes" 49). Goethe is, according to Nietzsche, the perfect example of a soul like that. The "highest man [der höchste Mensch]," then, would be him "who displayed the antipodal character of life in strongest terms, as its glory and sole justification [welcher den Gegensatz-Charakter des Daseins am stärksten darstellte, als dessen Glorie und einzige Rechtfertigung]" (KSA 12:10[111], pp. 519-20). Goethe himself, however, is far from consenting to the pretension involved in Nietzsche's claim that the great man has to be regarded the measure of things. And Nietzsche seems to recognize this difference. Goethe concludes his Faust by staging man's striving toward the highest spheres where he, the fallible human being, finds grace and redemption and experiences elevation. Against the words Goethe puts into the mouth of Doctor Marianus, the last male speaker in the final scene of Faust II (lines 11989-90), "The vision is free here and the spirit elevated [Hier ist die Aussicht frei, / Der Geist erhoben]," Nietzsche objects, "But there is an inverse type of person who is also at a height and also has a free vision-but who looks down" (BGE 286). For an interpretation of Nietzsche's anti-Goethian stance, see Karl Pestalozzi, “Hier ist die Aussicht frei, der Geist erhoben.' Nietzsche liest Goethe," Nietzsche-Studien 41 (2012): 17-42.

16. Nicholas Rescher, A System of Pragmatic Idealism, vol. 2: The Validity of Values: A Normative Theory of Evaluative Rationality (Princeton: Princeton University Press, 1993), 130.

17. Plato, Politeia 515 c; cf. 518 d-e.

18. That justice, for example, or a perfectly "just man" could ever be realized or "attained" was never claimed by Plato himself. According to Plato, we have to be content with approaching such models (paradeigmata). See Politeia $472 \mathrm{~b}-\mathrm{d}$.

19. Cf. Michael Rosen, Dignity: Its History and Meaning (Cambridge, MA: Harvard University Press, 2012), 13-18, 47-51.

20. De officiis I, 30, 106.

21. Immanuel Kant, "Lectures on Pedagogy," in Anthropology, History, and Education (The Cambridge Edition of the Works of Immanuel Kant), ed. and trans. Robert B. Louden and Günter Zöller (Cambridge: Cambridge University Press, 2007), AK 9:488.

22. Friedrich Schiller, "Über Anmut und Würde," in Sämtliche Werke, vol. 5, ed. Gerhard Fricke and Herbert G. Göpfert (Munich: Hanser Verlag \& Wissenschaftliche Buchgesellschaft, 1993), 472. 
23. Friedrich Schiller, "Was heißt und $\mathrm{zu}$ welchem Ende studiert man Universalgeschichte?," in Sämtliche Werke, vol. 4, ed. Gerhard Fricke and Herbert G. Göpfert (Munich: Hanser Verlag \& Wissenschaftliche Buchgesellschaft, 1980), 751. 24. Schiller, "Was heißt und zu welchem Ende studiert man Universalgeschichte?," 751.

25. "Ach, der Glaube an seine Würde, Einzigkeit, Unersetzlichkeit in der Rangabfolge der Wesen ist dahin,-er ist Thier geworden, Thier, ohne Gleichniss, Abzug und Vorbehalt, er, der in seinem früheren Glauben beinahe Gott ('Kind Gottes', 'Gottmensch') war [... ]' (KSA 5, p. 404).

26. Nicolai Hartmann, Zur Grundlegung der Ontologie (Berlin: de Gruyter, 1965), 46. 